\title{
Korean Private Participation Investment in Infrastructure
}

\author{
: Lessons and Implications for Egypt
}

Jun Yeup Kim / Protessor, Kyung Hee University

Hazem Mahmoud Abdel Aleem Mohamed / Economist, Minislry of Finance, Egypl

\section{[ 요 약 ]}

본 논문은 한국의 민간참여 인프라투자사업(PPI)방식이 어떻게 성공을 거두었으며 그러한 성공요인들 을 분석하여 개발도상국인 이집트정부에서 추진하는 민간참여 인프라투자사업에 대한 시사점과 함의 를 제공하고자 한다. 본 연구를 통하여, 한국정부는 리스크 분산관리(Risk Sharing)방식으로 민간참 여 인프라투자사업에서 예측하지 못한 위험을 효과적으로 완화 시키는 것으로 밝혀졌으며 보다 구체 적으로 민간참여업체들간에 리스크를 효과적으로 적절히 분산시키는 정부의 역할이 중요하다고 할 수 있다. 또한, 한국정부는 리스크 분산관리방식으로 Build Transfer Lease(BTL)를 민간투자사업에 도 입함으로써, 경제적 인프라구축으로부터 사회적 인프라구축으로 보다 더 영역을 확장하였다. 본 연구 를 통하여, 이집트는 민간참여 인프라투자사입의 도입초기단계로 리스크 분산관리방식이 적절히 이루 어지지 않았던 것으로 밝혀졌다. 따라서 본 논문에서 이집트정부는 효율적인 리스크 분산관리에 관한 법령의 개정과 함께 제도조직의 개편을 제언하고자 한다.

\section{[ Abstract ]}

This paper at tempts to answer the question of how Korean private participation investment in infrastudure(PPI) successful experience can provide lessons and Implications for Egypt. The study found that Korean government could shift to an efficient PPI system by employing a new Risk Sharing Approach which helped Korea to mitigate the unexpected risks in PPI Projects. The new Risk Sharing Approach was achieved through a successive government enabling role; policies and institutions that were being able to minimize the PPI risks to its lowest levels, and eftectively allocate the risk among PPI partners. With the introduction of BTL scheme to a PPI risk sharing approach, Korea expands the PPI scope from economic to social inf rastructure sectors. On comparing the PPI system in Egypt to Korean model, we found that Egyptian PPI system had not properly employ a PPI risk sharing approach. Accordingly, it is recommended that, Egyptian government has to adopt a set of institutional and reguatory amendments for the aim of adopting a risk shanng approach to the PFI system. 


\section{I . Introduction}

Public Private Partnerships (PPP) have become prominent over the last decade, fuelled by insufficient investment in the economy, growing pressures on government budgets and a general concern about inefficient service provision by state owned enterprise (OECD 2007). Private participation investment in inf rastructure (PPI) is a form of PPP that enables the private sector to work in cooperation with the public sector for providing infrastructure facilities (MOSF 2008a). PPI has taken place mainly in economic infrastructure, such as telecommunication, power, and transportation. However, attention has also shifted to social infrastructure, such as education, health, welfare facilities, and housing, as well as environmental sector. Traditionally, those services have been provided by the public sector for being less attractable to the private sector mainly due to its difficulty to attain reasonable return on investment, and difficulty to collect fees from users (Jefferies, Mc George, Cadman, and Fing, 2007), and (MOSF 2008b). The desire of greater efficiency, better services and the need for additional sources of finances without imposing a greater burden on the tax payers grasped new tools to PPI approach to fit for those sectors.
The rapid increases in the world population, economic growth, and industrialization, pose real challenges on infrastructure development represented by; a massive increase in the demand for infrastructure facilities, and which in retum impose burden on the countries budget, and lead to an inefficient service delivery (ADB 2008). Traditionally, the main source of financing infrastructure has been government finances including; taxes, public bonds, and user charges. Nevertheless, as the size of the economy becomes bigger, the government role is minimizod, and a more role is given to the Private sector (KRIHS 2005, 21). The PPI emerged as a tool that enables the private sector to be involved in financing, constructing, designing, operating, and managing the infrastructure projects through a set of schemes including; the BOO, BOT, BTO, and BTL (MOSF 2008c)

The PPIs offer benefits to the countries employing them represented by: (1) Providing additional resources of finance to meet the increase in demand for infrastructure faculties (2) Encour aging the private sector to utilize its professional skills, creativity and innovation through the infrastructure projects. (3) Ffficient delivery of services. (4) Assurance of on-time, on-budget delivery. Transferring certain risks to the private sector and providing incentives for 
assets to be properly maintained. (5) Low ering the cost of infrastructure by reducing both construction costs and overall lifecycle costs (Eggers and Dovey 2006; OECD 2007; Allard and Trabant 2008; World Bank 2007a).

PPI risk management has been a crucial issue for a PPI success. According to (Weatherall 2004, 3) A PPI is a risk-sharing relationship between the public and private sectors to deliver a desired public policy outcome and/or public service. A PPI risk could only be properly managed if allocated to the best party being able to bear them (Quiggin 2006, 291, 293). In other words, an efficient risk management entails the government success on the allocation of the PPI risk related to; construction, management, financing, and operation among the parties who are being able to best control and to manage.

The government polices and institutions that decide on selecting, and allocating the risks among the parties in the individual PPI contracts play an important role in the success of a PPI system. The government role is also crucial for minimizing moral hazards that might occur in PPI projects. A moral hazard describes a change that happens to the individual behavior leading him to behave in a careless way due to receiving overprotection. In a PPI projects, moral hazard could occur due to two factors: (1) Information asymmetries in ontract renegotiation. (2) Unfair bidding process that permits only a limited number of producers to enter the bidding. The Information asymmetries happens when the government provide the access to information, or a big financial support only to a specific project in the case it does not want to allow the project to fail or when the political cost of the project failure is too high. Theover protection of specific project, or restricting the PPI bidding for specific projects lead the protected parties to be less concerned if a contract fails or falters, and having no incentive to minimize projects costs and maximize its revenues, leading in return to projects distress or failure (Parker, 2007, 2, 8, and 10; Ho, 2007, 22; Spellman and Walker, 2006, 5, 12, and 32).

Iossa and Martimort (2008) and Parker (2007) argued that due to nature of the PPI long life contracts $25-30$, a set of un expected risks might happen within the project contract time related to: the depreciation of the assets prices, or change in the value of currency, or change in regulations, or change in technology. And those risks will be bearded by the private sector alone if the government did not identify from the beginning how the unexpected risks could be allocated effectively to each party. In that case the risks bearded by the private sector would be 
reflected as an incredse in the services prices. Accordingly, they suggested that a set of methods could be employed by the government to mitigate the unexpected risks in a PPI as follows; (1) Early anticipation of future risk and its effective allocation to the contracted parties. (2) Fiffective contracts renegotiation about additional subsidies to support projects facing financial difficulties. Again only the effectiveness of the govermment policies and institutions could assure the success of the PP system. For example, an ineffective Renegotiation Deal that provides overprotection for a specific project to avoid its fail might lead to increasing the risk of moral hazards as was mentioned by previously studies. On contrary, ef fective government role could mitigate the PPI risks and challenges. In Sum, a government enabling role is crucidl for a PPI success.

In a recent global trend many inter national organizations such as World Bank, OECD, ADB, and the United Nations encourage the countries worldwide to a great extent to introduce the PPI sy stem due to the benefits it offers for the countries. The PPI international experiences proved to deliver excellent value for money and much faster delivery than would have occurred with traditional procurement. In line with the global trend, Korea firstly introduced its PPI system in 1994; with the promotion of "Private
Capital into Social Overhead Capital Investment Act, at the first years of its establishment the Korean PPI system failed to achieve its prospected outcomes of attracting the private sector to invest in the infrastructure projects. By 1998, only 18 local government infrastructure projects were launched. "The slow progress of PPI during these years has been attributed to; a lack of transparency, excessively complicated procedures, insufficient incentives to the private sector, and unattractive risk sharing arrangements, additionally the 1997 financial crises lowered the private sector appetite for PPI in Korea" (World Bank 2007a, 52).

While almost after three year of its establishment, the Korean Government could successfully understand the shortcoming of the PPI program and with the revision of the PPI Act in Jan. 1999 the PPI system turned to be successful. "South Korea could reach to an advanced stage in promoting Public-Private Partnerships in the development of economic and social infrastructure, through effective PPP Legislations, and institutions" (UNESCAP 2007a, 17). The Korean PPI share of the total infrastructure investment rose from 3.8 percent in 1998 to 14.0 percent at 2007 , at the meanwhile the public expenditure declined from 96.2 percent to 86.0 percent during the same period (MOSF 
2008d, 13). It indicates that the success of the PPI system motivated the Korean government to shift its policy toward giving important roles for the private sector and a diminishing role for the public sector in financing infrastructure.

Korea could successfully shift in a short period of time from an inefficient PPI system to an efficient system and which could happen as a result of a government comprehensive regul atory and institutional reform program that implemented an efficient PPI Risk Sharing Policy. Moreover, the Korean government could further utilize a deeper development to its PPI Risk Sharing approach to fit with the new global develop ments and that enabled the PPI to expand its scope through extending its investment from the economic to the social inf rastructure sectors. Main issues highlight the importance of this paper. This paper attempts to answer following questions: how Korea can improve the PPI Risk Sharing Approach to allow PPI expand its scope from the econom ic into social infrastructure sectors given that the later are less attractable to private sector? How Korean PPI successful experience could provide implications for the government of Figypt in those sectors? The structure of paper comprises four sections; section one is the introduction: section two presents how a New PPI Risk Sharing Approach had improved the Korean PPI Performance through the period after 1998 up to date and the expansion of PPI scope to support Korea's Social Development plan. Section three provides main findings and implications for the Arab Republic of Figypt on how Korean PPI system could promote the private sector investment within Two Selected Sectors; Education, and Environment: Water Sewage. And finally, Sectionfour is the onclusion.

\section{Efficiency of the Korean PPI system}

Over the past decades, South Korea had made tremendous efforts in improving the environment sector. For instance in the water sew age facilities, both the quantity and quality had improved in the last 10 years. In a way to address those problems, the Korean government policies were switched from the construction of large-size sewage treatment facilities to the construction of small-size sewage treatment facilities to reach the areas that need full coverage. Secondly, the improvement of the operation and management of existing plants. Consequently, the PPI investment had been promoted in Environment sector since 2005. As of 2007, 17 BTL projocts had been allocated for 
the new installation, replacement, repair, and the improvement of sewage pipes with a total investment of US $\$ 5.5$ billion and covering 61 sewage treatment areas under 29 local selfgoverning bodies ( 3 metropolitan cities and 26 cities and counties).

The PPI projects were implemented through BTL scheme, under which; private sectors builds and operates the sewage pipes with their own funds and transfer the ownership to the government or local self-governing bodies or lease them to recover the investment. During the term of lease, local self-governing bodies pay the operators the total amount of investment including construction costs, interests and management expenses in oqual installments. According to (MPB 2007, 18) “Build-Transfer-Lease (BTL) scheme was introduced to utilize private funding and concentrated on distributing appropriate facilities at the earliest convenience." The aim of the PPI implemented scheme was to enable the Korean sewage Sector in utilizing private capitals within a short period of time, and enhancing the operation and the manag ement of the sewage treatment plants. Also through the BTL the Korean government set the rules for inclusion of SMEs for at least $67 \%$ of total private participation in Sewage. The following table presents the total BTL investment in the Korean sewage pipes through the period 2005-2007.

As can be seen from table 1 Korea's BTT, investment in Sewage Sector accounted to US\$ 5.6 billion in 2007, of which US $\$ 3.9$ billion private investment. As can be noticed the BTL investment allocated for the years 2006, and 2007, represents more than two folds if compared to the first year of the project implementation, and which reflects the increase in the government confidence in using BTL for the PPI implementod projects in the Sewage sector. The increased BTL investment during that period aim ed to extending sew age pipes to a total of $8,824 \mathrm{~km}$, thereby increasing the sewage supply rate from $68.1 \%$ in 2004 to $75 \%$ in 2007 , in

(Table 1 ) Korea's BTL investment trend in Sewage Sector(2005-2007)

\begin{tabular}{l|c|c|c|c}
\hline \multirow{2}{*}{} & \multirow{2}{*}{ Total } & \multicolumn{3}{|c}{ Investment size by year } \\
\cline { 3 - 5 } & & 2005 & 2006 & 2007 \\
\hline Volume (km) & 882.4 & 157 & 351.1 & 374.3 \\
\hline Contract amount (billion Won) & $5,6^{-4}$ & 1,000 & 2.307 & 2,307 \\
\hline
\end{tabular}

Source: Miristry of Environment, Kored Environmental policy Bulletin 
addition to improving the service quality, reflecting the benefits that BTL scheme offers to the Sewage sector in Korea.

\section{Case Study from the Korean PPI} experience in the Education sector

Since its introduction in 2005, the BTL scheme had helped the Korean PPI system to build 51 Universities \& Colleges, in addition to building 973 elementary \& socondary schools. As can be seen from table 2 with the introduction of the BTL scheme in 2005, the total number of schools and universities increased from 255 PPI implemented projects to a total of 1,024 in 2007.

Through the PPI school projects the private sector provides the construction, maintenance. After the completion of the infrastructure facility, the concessionaire lease the facility to the government and the concessionaire is given the right to operate the facility (and receive government payment for a specific period of time), and after the end of the concession period the lease ownership is transferred to the government.

Within the Schools projects the PPI system had helped in the construction of new schools, refurbishment of old facilities, expansion of facilities in need such as gymnasium, auditorium. As for the universities it helpod in construction or expansion of dormitories and faculty residence, or the construction of a whole university campus. Additionally, the Korean PPI system gave concern for the establisment of community schools. That kind of school includes combining several cultural, and welfare facilities into one school facility. The Culture includes establishement of : Library, Sports facility, Youth

〈Table 2 > Korea's BTL investment trend in Sewage Sector (2005- 2007)

\begin{tabular}{|c|c|c|c|c|c|c|c|c|}
\hline \multirow{2}{*}{ Facil ties } & \multicolumn{2}{|c|}{2005} & \multicolumn{2}{|c|}{2006} & \multicolumn{2}{|c|}{2007} & \multicolumn{2}{|c|}{$2005-2007$} \\
\hline & EA & Amount: & $E A$ & Amourt & EA & Amourt & EA & Amoun \\
\hline Univ \& College & 30 & 5.825 & 9 & $\because 95$ & 12 & 4,031 & 51 & $1 \longleftarrow .051$ \\
\hline $\begin{array}{l}\text { Elementary } \\
\text { \&Secondary } \\
\text { School }\end{array}$ & 225 & 13.101 & 265 & 26,216 & 183 & 19,973 & 973 & 59.593 \\
\hline Total & 255 & 19,279 & 274 & 27,411 & 495 & 24,004 & 1,024 & 70,644 \\
\hline
\end{tabular}

Source: Ministry of Environment, Kored Environmental policy Bulletin 
training facility. While welfare includes: Childcare facility, Public health \& medical facility. Examples of the community schools under the PPI are: 9 projects had been implemented in Kangjin multi-complex in 2005. And 11 projects had been implemented in 2006 in Injae multicomplex. Furthermore, Centum High School in (Busan), and Shindorim High School (Seoul) are currently under constuction, and are set to be open in January, 2009.

\section{Case Study Building University Dormitories}

- Project Name: Building Student Residence for National Universities in Daejeon /Chungnam Province

- Competent Authority: Chung nam University and 3 Other Universities

- Concessionaire: Chungram Eduvill Co., Lta

- Investment: Total amount of investment: 88.7 billion KRW (U\$95million)

\section{$\underline{\text { Project }}$}

- Construction of Chungnam Univeristy: 1,348room dorm

- Construction of Kongju University: 617-room dorm

- Construction of Hanbat University: 300-room dorm

- Construction of Gongju University of education: 227-room dorm.
Total Number of established rooms: Total 2,492 rooms in 4 Universties.

\section{Lessons learned from BIL Scheme}

1- Fffective Risk Allocation Approach: through transferring the construction and operational risks to the private sector, thereby minimizing the threats in PPI long life time projects and that might lead to changes in asset prices, or change in currency value. On the other hand within the framework of the PPI Act, a set of incentives were provided to the private sector, in order to help him mitigate any unexpected risks during the long life nature of the PPI contract including: Minimum Revenue Guarantee MRG (to avoid change in market condition risk), Risk Mitigation for foreign Exchange Risks (to avoid change in asset prices and cur rency devaluation), Buyout Rights \& Compensation on Termination Payments (to avoid project failure risk), tax incentives (to attract the private sector to PPI projects).

"In social infrastructure projects Government will be acquiring services, rather than assets. Accordingly, Government should not bear a ny a sset related risk. In other words, Government should not bear construction or 
commissioning risk, asset depreciation, technological obsolescence risk, operating risk or other similar risks associated with asset ownership" (Rawlings 2002. 2), as well as (Flannery and Craven. 2002, 2)

2-Improving the efficiency of the service delivery through the Government supervisory Role.

3-Providing a room for the SME to participate in PPI projects.

4- The BTL is considered to be more suitable for the social infrastructure facilities, as theses sectors have the common characteristics of: low return, and difficulty to obtain retum in investment. And which is assured by a regular payment to the private sector, instead of colleting the users fees.

5-The Change in the Government regulations does not lead to project failure, as the private sector is paid regular installments. For instance, in the schools the government can easily change the regulations regarding the number of students in class, or education hours. or usage of building after school hours for other activity.

6-Effective Risk allocation of PPI tasks among the different parties acoording to the concept of the best to control and mange. Risk diversification leads each party to be specialized in his own task in PPI project, thereby enhancing the project efficiency.

\section{Orrent PPI system in Egypt}

Over the past few decades, the Egyptian government has been the major provider of infrastructure projects. However, with a multiplying population, an expanding, economy, and increasing financial obligation, the public sector could hardly maintain its role as the sole provider of infrastructure projects. The inability of the public sector to maintain his role was further confirmed by the bad state of the publicly financed infrastructure projects and their inability to meet their economic as well as social goals.

Accordingly, The Egyptian government started employing a PPI ap proach since 1990. At the beginning, the PPI system was limited to three infrastructure sectors: Energy, Telecom, and Transport.

As can be seen in Table 3 through the period (1990 2004) only 16 projects involving investment commitments of US $\$ 6.2$ billion reached final closure where the telecom sector received the largest share of investment. On comparing the Egyptian PPI investment too the developing countries through the same period it is noticod 
〈Table 3 〉 Egypt Pivate Participation in Infr astructure projects by Sector (1990 2004)

\begin{tabular}{c|l|c|c}
\hline Sector & \multicolumn{1}{|c|}{ Sub-Sector } & Number of Projects & Total Investment \\
\hline Energy & Electricity & 3 & 1,158 \\
\hline & Natual Gas & 4 & 220 \\
\hline & Total Energy & 4 & 1,378 \\
\hline Telecom & Telecom & 4 & 3986 \\
\hline & Total Telecom & 6 & 398 \\
\hline Transport & Airpors & 2 & 461 \\
\hline & Seaports & 8 & 859 \\
\hline & Total Transport & 0 & 0 \\
\hline & Total Education & 0 & 0 \\
\hline
\end{tabular}

Source: World Bank PPI

that the Egyptian PPI still remains very limited. For example within the sameperiod, Czech Republic PPI achieved US \$16.8billion, and Colombia achieved US $\$ 14.7$, while South A frica achieved US $\$ 18$ billion. As for South Korea it achieved US $\$ 33$ billion, Moreover, it could be noticed from table 1 that there were no PPI in vestment in the Fducation, and the Environment Sectors through 1990 till 2004. Actually, the PPI for those sectors had been recently introduced in Egypt since 2006.

\section{1) Current challenges of Social and Environment Sectors}

In a recent trend, the Egyptian government started encouraging the inducement of the private sector as an important contributor to the economic development plan, and this started with the beginning of the national five year development plan (2002 2007) where it was stated that "In order to attain a $6.2 \%$ GDP growth rate by 2007 , investments were estimated to increase from $16.9 \%$ of GDP in 2002 to reach $19.8 \%$ in 2007 . This is likely to occur through encouraging private initiatives, as the private sector's share is expected to reach about $60 \%$ of the Plan's target investment. Naturally, this requires opening the door for the PPI in infrast ructure services". Accordingly, the Egyptian government raised the PPI investment for the economic infrastructure amounting to 
US\$ 15.3 billion in 2007. Even though the efforts done by the Egyptian government in promoting the PPI investment in infrastructure. The infrastructure challenges remain in a prominent position. The following takle presents the huge in frastructure gap resulting from the increase in demand for the infrastructure faculties in Egypt in 2007. As can be seen in table 4 only US\$ 4.3 billion represents the amount of the available infrastructure spending in 2007, compared to an amount of US\$ 8.2 billion representing the total infrastructure investment needs for the same year, and which in return creates an infrastructure gap of US\$ 3.9 billion. This huge infrastructure gap provides an indication that the Egyptian infrastructure is still facing great challenges.

Egypt's infrastructure challenges for the social and environment sectors. Firstly, within the education sector the Egyptian government spends around $19 \%$ of its total expenditure on education, roughly $5 \%$ of GDP; this is considered one of the highest ratios in the world. However, the expenditure on education is not enough due to the misallocation of government expenditures. Additionally, most of the expenditures are allocated on the construction of new buildings and classes, and there is a lack of allocation of resources for the maintenance of the school buildings. The Bureaucracy and lack of transparency are the most contributors to inefficiency of the institutional framework, and which result in double counting, and misallocation of resources and above all mismanagement of the expenditure process.

Moreover, another major concern in the

(Table 4 ) Egypt Infrastructure Needs in 2007

\begin{tabular}{l|c}
\hline \multicolumn{1}{c|}{ Egypt } & 2007 \\
\hline \hline GDP Growh Pate & $7 \%$ \\
\hline GDP & -16.7 (Billion US\$) \\
\hline Currert Infrastructure Spending & 4.3 (Billion US\$) \\
\hline Needed Infrastructure Sperding & $(3.7 \%$ of GDP) \\
\hline Infrastucture Gap & 8.2 (Billion US\$) \\
\hline
\end{tabular}

Source: Un, Paul Noum ba ¿J08. Econom ics Support Unit, World Bank. "Egypt PPPCapacity Developm ent Support" Presented at the World Bank Egypt PPP Development Conference in Egypt, May 12th, 2008 
educational sector in Egypt is the problem of the crowdedness of the students in the classroom. According to the Human Development Report "In Egypt, $40 \%$ of the schools have a class density far exceeding the average of 40 children per classroom; in fact many classes reach 80 students which makes learning of any kind virtually impossible". "Additionally, the kinds of furniture used are not fitting for activity-based learning" (HDR 2005, 20). Over and above, al though Fgypt has made major strides in access to education with an enrolment rate reaching a level above 90\%. HDI Education index reveals the uneven progress between different regions inside Egypt, where the lower Egypt lag far behind the Upper part. On the other hand on assessing the quality of internet access to schools and universities in Egypt, the HDR shows that it is considered to be in adequate. And this is attributed to a limited number of $\mathrm{PC}$ penetrations per school and limited bandwidth.

Secondly, the infrastructure challenges facing the environment sector, the existing water and sanitation services are considered to be poor in terms of quantity, and quality. Also, there are disparities in the services quantity and quality between and within governorates, particularly betw $\oplus$ n the urban and rural parts in Egypt, where it goes for that sake of the urban parts.
According to (HDR 2005, 25, 178) "The number of people without access to sanitation in Upper Egypt is alarming when compared to the same number in other regions", furthermore the estimated damage costs resulting from a low water and sanitation qualities were set to he I.F. 5.35 billion in 2003 or $1.8 \%$ of GDP.

\section{2) New PPI Program tor Expanding PPI Scope}

The government of Egypt had recently planned to expand PPI scope for the social and Environment Sectors. Consequently, a new PPI program was adopted in June 2006 with the aim of expanding PPI scope to reach social and environment sectors such as; Education. Water Sewage, and Health sectors. The New Egyp tian PPI program complies greatly with the one implemented by South Koread and that in terms of: the responsible bodies handling the system, the criteria at which the procurement process is based Value of money VFM, and the steps by which the PPI eligible facility types are chosen. However, the Figyptian new PPI program is considered to be in its early stages of developments, where all PPI projects are still in the selection process, in addition to the PPI Projects are set to start implementation through the period (2008 2012).

Moreover, the Egyptian New PPI program 
complies with the one implemented by the Korean government in terms of the similarity of the two programs in giving more concern to specific sectors within the social and environment sector which are: education and sewage sectors. The following table shall elaborate more on the Egyptian government concern on promoting two specific sectors (education and sewage) within the Social and Environment sectors.

Table 5 presents the total investment allocated within the New Egyptian PPI program for the Social and Environment pipeline projects. As can be seen from the table the total investment allocated for the PPI investment for the social and environment sectors accounted to US\$ 6.12 billion in 2008, of which the largest portion is allocated to the Education sector accounting to US\$ 5.00 billion, followed by the wastew ater treatment Plants recoding US\$2.20 billion. And that reflects the similarity between the Egyptian and Korean Model in giving more concern to those specific sectors within the Social and Environment sector.

According to (Fgypt PPP National Program 2007, $45,52)$, the Egyptian pipeline projects planned for the Educiation Sector includes the building of new 2210 public schools: the project will be divided in to 7 batches within a period of 5 years. The first stage of the project includes the establishment of 300 schools covering 27 governorates with a total of 4903 new class rooms. Through the PPI schooling project the private sector provides the construction, maintenance, and non educational services including: cleaning, security, and help desk. On the other hand the government provides the educational services and pays anmual fees for the private sector covering the construction, and maintenance cost, and the returns for the

(Table 5 ) Egypt PP| Pipeline* Projects in Social and Environment Sectors, as of 2008

\begin{tabular}{c|l|c}
\hline \multicolumn{1}{c|}{ Secto } & \multicolumn{1}{|c}{ Facility Type } \\
\hline \multirow{2}{*}{ Total Social Intrastructure } & 6.12 & 5.00 \\
\hline \multirow{2}{*}{ Total Environment Sedor } & Education & -2 \\
\cline { 2 - 3 } & Heath & \\
\hline & 2,20 & 2.20 \\
\hline
\end{tabular}

Souroo: Egyptian Ministry of Financo. PPP Contral Unit 2008. "PPP Dovolopmonts in Egypt" Prosontod at the World Bank Egypt PPPD evelopment Confercnoe in Egypt May 12th, 2008. "Pipeline Projocts: Current PPI Projects that are rcady to bolunched during Period (2008-2012). 
services provided by him.

As for the pipeline projects for the Environment Sector, the importance of the environment sector on improving the overall productivity and improving the onsumer's health called the attention of the Egyptian government to employ a PPI system in that sector. In order to meet the challenges of the fast growing urban population and particularly to address the burden of overcrowding in the capital city Cairo, the Egyptian government started promoting the development of new urban cities, such as the New Cairo city. With a limited govemment budget this plan would not be achieved. Consequently, a PPI system is planned with a master plan to build new Wastewater Treatment Plants with a treatment capacity of 1.25 million cubic meter/ day (to be implemented on three Phases) and with a total estimated cost of 2.5 billion. The first phase of this master plan consider the construction of a Wastewater Treatment Plint with a capacity of 250,000 cubic meters per day and is expected to be operational in 2010. The project Service Area covers the New Cairo City.

\section{3) PPI Regulatory and Institutional Framework in Egypt}

The Egyptian PPI regulatory framework is organized according to a guideline issued by the Ministry of Finance; there is no specific law that exists for the PPI projects. The PPI guide line set the rules governing PPI program including: Rules for Selecting PPI projects, Defining Eligible Facility Types, Implementation Scheme Process, in addition to Rules for Termination mechanisms, and Role of Public and Private Parties in PPI project. Even though, the guideline covers the major issues in the PPI system. However, it does not provide international fixed norms or standards for PPI projects, rather it depend on the advices provided by the international advisor appointed to the case by case project. Moreover, for the approval of a PPI selected project the parliament has to ratify the case by case project.

As for the Egyptian PPI institutional framework, there are no organizations established under the PPI system. Instead, the Central PPP Unit achieves most of the PPI system activities. The Central PPP Unit is under the Authority of the Ministry of Finance it is tasks inchdes; Creating and implementing framework for Egypt's overall PPP program, assisting awarding authorities in the selection of PPI projects, coordinating the PPP national progra $m$ across $m$ inistries and public bodies, promoting the national РГГ initiative, and developing PPP best practices, models, and standards for Egypt. 
Finally the selection process of the PPI projects is conducted according in Two Stages as follows: (1) PQ (Pre-Qualified Evaluation): Pre-evaluation of the projects prop osal before being accepted to enter the tender, and is followed by renegotiation with the private parties to reach on a final proposal. (2) Main Evaluation (Bidding): selection is based on Technology and best Prices. Within the First Stage the PPI along with PPP Satellite Units within the procuring ministries decide on the approval of the PPI project to be promoted to enter to the second procurement stage, at that stage an international advisor is appointed for the case by case project to assist in evaluating the PPI projects to be selected. Furthermore, the Egyptian PPI selection evaluation process is conducted according to VFM Value of Money techniques. Additionally, only the solicited projects are allowed in the Egyptian PPI system.

\section{Main Findings: Role of Government in the PPI System - Egypt and South Korea}

The following table presents a summarized comparison of the government role in the PPI system in the Republic of Korea, and the Arab Republic of Egypt for the aim of pointing out the similarities and the differences between the government role in the two countries, followed by an analysis of which policies and institutional framework had benefited the Korean government in implementing the PPI reform program in order to draw lessons for the Arab Republic of Figypt.

As can be seen in table 6, the overall structure of the PPI System employed by the Egyptian government complies greatly with that implemented in South Korea and that in terms of; the responsible bodies handling the system, the criteria at which the procurement process is based Value of Money VFM, and the steps by which the PPI eligible facility types are chosen. However, the Egyptian PPI system does not employ a risk sharing mechanism, and this could appear in the absence of the necessary regulations, and institutions in PPI system

As table 6 presents, the set of regulations and institutions that the Egyptian governm ent lack and are found in the Korean model are as follows; firstly, the Egyptian PPI system does not have specific law for PPI projects, rather the PPI procedures are organized according to PPI guide line issued by the Ministry of Finance. The guide line misses important things found in the law as follows: Parliament has to ratify the case by case project; the Guide does not provide international 
〈Table6 > Role of Govemment Comparison between Egypt and South Korea

\begin{tabular}{|c|c|c|}
\hline ttem & Egypt & South Korea \\
\hline Responsible Miristry & Ministry of Finance & Ministry of Strategy and Finance \\
\hline $\begin{array}{l}\text { Roke of Rexp onsible } \\
\text { Ministry }\end{array}$ & \multicolumn{2}{|l|}{$\begin{array}{l}\text { Development of Primary PPI policies and } \\
\text { establishment of comprehensive investment plans. }\end{array}$} \\
\hline PPICentra Unit & $\begin{array}{l}\text { Central PPP Unit, } \\
\text { under the direct supervision of the Mirister, } \\
\text { Its major Role: } \\
\text { - I Create and implenent framework for Egypt's overal } \\
\text { PPP program } \\
\text { - Selection process of PPl projects. }\end{array}$ & $\begin{array}{l}\text { Private investment Committee. underhe direct } \\
\text { supenvision of the Mirister. } \\
\text { Its Role: } \\
\text { - I Designates central menagenert. PPI projects and } \\
\text { concessionaires }\end{array}$ \\
\hline $\begin{array}{l}\text { Others Ministries } \\
\text { participating in PPl } \\
\text { program }\end{array}$ & $\begin{array}{l}\text { - I PPP Satellite Units within the Procuring Ministies: } \\
\text { - I Ministry of investrment; } \\
\text { Responsible for: exsyaccess for irfomration to hvestors, } \\
\text { promotion tor PFI workd wide. }\end{array}$ & - I PPP procuring Ministries. \\
\hline $\begin{array}{l}\text { Criteria for Selecing } \\
\text { PPIProjects }\end{array}$ & - VFM Value of Money Mechanism & - VFM Vaue of Money mecharism \\
\hline $\begin{array}{l}\text { Incentives and Pisk } \\
\text { allocation } \\
\text { Mechanisms }\end{array}$ & $\begin{array}{l}\text { - Specific incentives given to the PPI Projects, they } \\
\text { are treated as ordinary public and private projects. } \\
\text { - MechanismsempbyedtoPFProjects }\end{array}$ & $\begin{array}{l}\text { A) Risk Sharing Mechanism that indudes: Minimum } \\
\text { Revenue Guaranten MRG. Fisk Mitigation for toreign } \\
\text { Exchange Pisks. Buyout Pights \& Compensation on } \\
\text { Termination Payments. } \\
\text { B) Financial Supp or Mechanism that includes Tax } \\
\text { benefits, Construction subsidies. and freedom on } \\
\text { detecting the returnon investment. discussed in a bief } \\
\text { in (Section 3.4) }\end{array}$ \\
\hline $\begin{array}{l}\text { Seq arate } \\
\text { Organizations in } \\
\text { PP System }\end{array}$ & $\begin{array}{l}\text { No Separate organizations, all the PPI tasks are } \\
\text { under taken by the Central PPP Unit }\end{array}$ & $\begin{array}{l}\text { - PIMAC: Public Private Infr astructure Investment } \\
\text { Management Center } \\
\text { - KODT: Korean Credit Guarantee Fund }\end{array}$ \\
\hline \multirow[t]{2}{*}{ PP Legal System } & PPIGuideline, No specific Law for PP Projects & PFIAG \\
\hline & $\begin{array}{l}\text { Regulates the rules governing PF/ program including: } \\
\text { Types, Implementation Scheme Process. Rules for Term }\end{array}$ & $\begin{array}{l}\text { ulesfor Selecting PPI projects, Defining Eligible Facil ity } \\
\text { ration mectanisms. Role of Public and Private Parties }\end{array}$ \\
\hline Annual PPI Plan & No Annual PPI Plan & $\begin{array}{l}\text { PPI Act issue an annual PPI Plan, and which } \\
\text { amounce the solicted PPl annually selected projects. } \\
\text { in add inion to identifying the following: } \\
\text { - The Long-term Development Objectives } \\
\text { - Investment Priorities } \\
\text { - National Policies and Strat egies for Infrast ructure } \\
\text { Development }\end{array}$ \\
\hline $\begin{array}{l}\text { PP Projects } \\
\text { Selection Process }\end{array}$ & \multicolumn{2}{|c|}{$\begin{array}{l}\text { Two Stagestor PP Selection: } \\
\text { 1) PQ (Fre-Qualified Evaluation): Pre-evauation of the projects proposal before being accepted to enter the } \\
\text { tender, and is folowed by renegotiation with the private parties to reach on a final proposal. } \\
\text { 2) Main Evaluation (Bidding): selection is based on Technology and bes Prices. }\end{array}$} \\
\hline
\end{tabular}




\begin{tabular}{|c|c|c|}
\hline tem & Egypt & South Korea \\
\hline $\begin{array}{l}\text { Authority } \\
\text { Responsible tor } \\
\text { Selecting the PP } \\
\text { Projects }\end{array}$ & $\begin{array}{l}\text { Cental FPP Unit in coordination with PPP Satellite Units } \\
\text { within the proc uring ministries appoits one inter national } \\
\text { adviso tor the case by case project. }\end{array}$ & $\begin{array}{l}\text { PIMAC } \\
\text { And which isa separate oryanization, } \\
\text { Empbys a high level of techrician experts wihin the major } \\
\text { fields related to the infrastucture sectors. and that have } \\
\text { high level of the projects evaluation technicues }\end{array}$ \\
\hline $\begin{array}{l}\text { The projects eligible } \\
\text { for PP| Selection }\end{array}$ & Only Solicited Projects & Both Solcited, and Unsolicited Projects \\
\hline PPI onestop service & No Specific organizajon for the PPI Projects. & PIMAC \\
\hline
\end{tabular}

Souroe: Authors own research

fixed norms or standards for PPI projects; with the absence of PPI law no incentives are provided to PPI projects.

Secondly, the Egyptian model does not provide any kind of risk sharing regulations in PPI system. On the other hand, the Korean model employ a set of risk sharing regulations, by which the government is committed to share a part of the unexpected risks with the private sector. Due to nature of the PPI long life contracts $25-30$, a set of un expected risks might happen within the project contract time related to; the depreciation of the assets prices, or change in the value of currency, or change in regulations, or change in tedmology, and which could be reflected in an increase in the services prices and that might lead to project distress or failure. The set of Risk allocation mechanisms introduced by the Korean government included: Minimum Revenue
Guarantee MRG (to avoid change in market oondition risk), Construction subsidies, and Risk Mitigation for foreig $n$ Fxchange Risks (to avoid change in asset prices and currency devaluation), Buyout Rights \& Compensation on Termination Payments (to avoid project failure risk), tax incentives (to attract the private sector to PPI projects).

Thirdly, the Selection process of the PPI projects; the Egyptian government does not have a separate organization that decides on selecting the PPI approved projects. In Egypt, the selection process is done through central PPI unit incorporation with the appointment of international advisor for the case by case PPI project. On the other hand, the establishment of the Public Private Infrastructure Investment Management Center PIMAC in Korea as a separate organization with a sufficient number of 
employed technicians and experts, has the advantage of improving the evaluation techniques for the selection process, thereby ensuring the selection of the best PPI projects among the different competitors, and an efficient risk sharing approach. Also PIMAC has the advantage of acting as a one-stop service for the PPI investors, thereby making it much easier for the private parties to deal with one specific organization rather than dealing with several government authorities and which gives incentive to the private parties to be attracted to PPI system

One more important thing is observed in the selection process of the Korean model, within the frame work of the PPI regulations; both the Solicited and the unsolicited projects are approved to be eligible for PPI projects. On contrary, the Egyptian model approves only the Solicited projects. The Unsolicited Project provides the private sector the opportunity of proposing new projects other than those originally planned by the government, thereby giving the private sector the opportunity to be more creative in proposing new ideas or thoughts that might have not been clearly observed by the government authorities. Additionally, in an Unsolicited projects cost effectiveness is ensured, because once a private sector offers a proposal of a new valuable idea or project based on an estimated cash flow statement. Under the unsolicited projects, other private sectors are allow ed to submit their proposals for the same project, thereby competition arises in the (PQ) stage, leading the project cost to be minimized to its actual margin, and resulting in cost effectiveness for the sake of the consumers.

Finally, the Korean model differs from the Fgyptian in the establishment of a separate organization; the Korean Credit Guarantee Fund KODIT, and which provides guarantees for the PPI projects, thereby, from one side, inducing the private sector to PPI projects, and from other side securing the PPI projects from a collapse that might happen due to any unexpected financial distress that could face PPI projects during their long life contract, Hence, assuring the sustainability of essential services for consumers.

In sum, on comparing the PPI system in Egypt to the Korean model, it was found that Egyptian PPI system does not employ a PPI risk sharing approach. In Korea, a new risk sharing approach was achieved through a successive government enabling role; policies and institutions that were being able to minimize the PPI risks to its lowest levels, and effectively allocate the risk among the PPI partners. Accordingly, it is recommended that, in order to enhance the efficiency of the 
〈Table 7) Lessons fom the Korean PPI Experience to the Egyptian New PPI Program in the Social and Environment Sectors

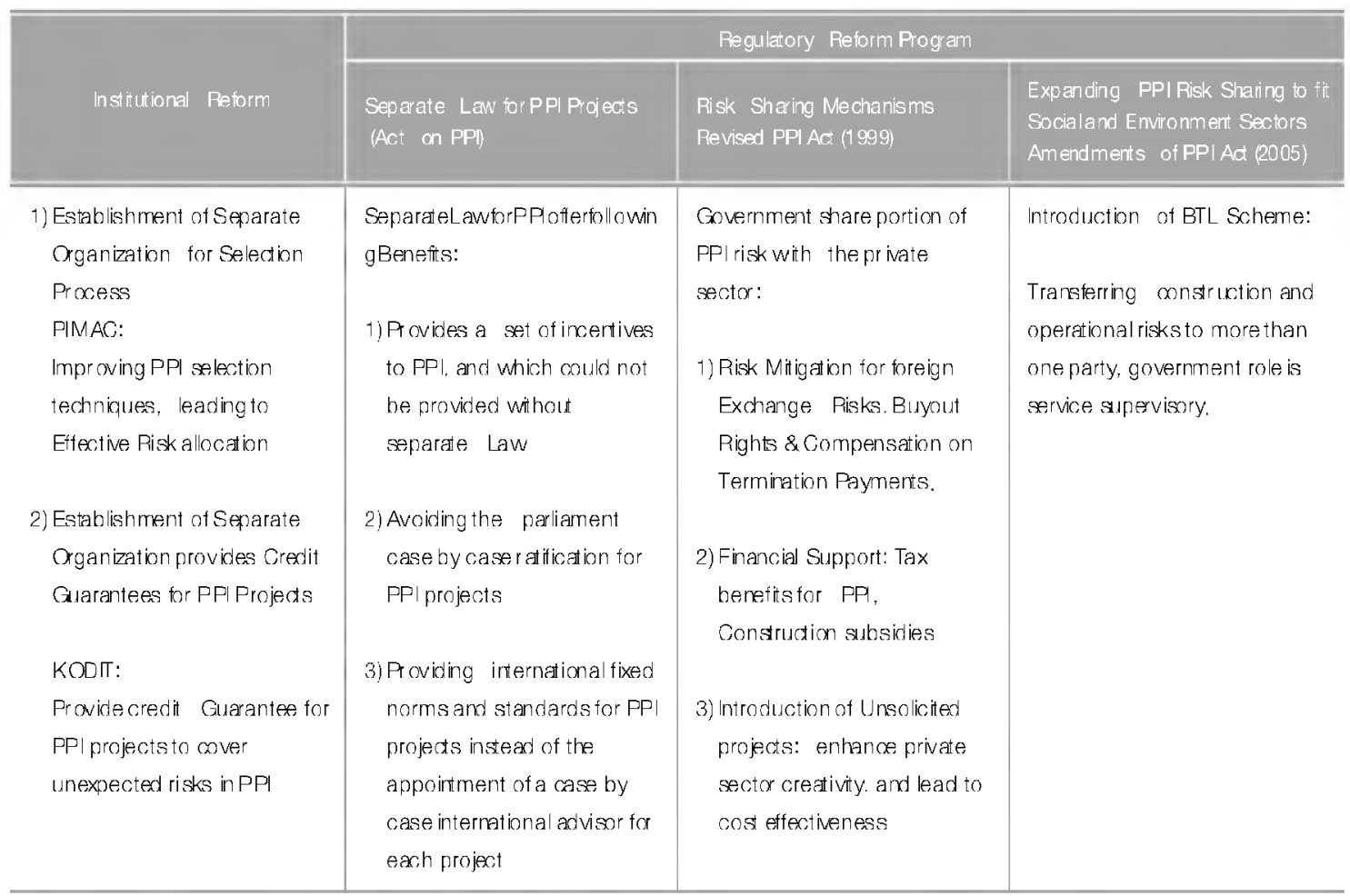

Source: Authors own research

Egyptian new PPI program, the Egyptian government has to adopt a set of institutional and regulatory amendments to its PPI system for the aim of adopting a new risk sharing approach as was employed by the Korean Model. Accordingly, the following table presents the lessons drawn from the Korean PPI Model to the Egyptian PPI system.

As can be seen from table 7 the set of regulatory and institutional reform recommended to be employed by the Egyptian model, and are found in the Korean Model are as follows:

- Regulatory Reform Program:

- (Revised Korean PPI Act in 1999); Government Sharing Mechanism,at which government Share portion of PPI risk with private sector, and that in away to minimize PPI Risks that mighth appen through PPI on glife contracts 25-30. These Risk sharing mechanismsin cluded the following: Risk Mitigation for foreign Ex change Risks, Buyout Rights \& Compensationon Termination Payments, in 
addition to the revised act introduced the Un solicited Projects to PPI eligible projects.

- (Amendments to PPI Act in 2005); Introduction of BTL to social and environment sectors, at which the PPI construction, and operational risks are transferred to more than private party, and the government role is restricted on the service supply and provision only.

- Act on Private Participation in Infrastructure PPI); Separate law for PPI Projects and which offers the following benefits: provides a set of incentivas, and which could not be provided without a separate law; avoiding the case that the parliament has to ratify the case by case PPI projects; providing international fixed norms and standards for PPI projects instead of the appointment of a case by case international advisor for exach project

\section{- Institutional Reform Program:}

- Establishment of PIMAC as a separate institution in order to the improve the PPI selecting process, and effectively allocates the risks between the PPI partners, in addition to its important role as a one-stop service for the PP investors.

- Fstablishment of KODIT and which; Provide credit guarantees for PP projects to cover PP unexpected risks.

\section{Conclusions}

Korea could shift in a short period of time to an efficient PPI system by employing a new risk sharing approach for its PPI System. In Korea, an Efficient Risk Sharing Approach was employed through a successive govemment enabling role, achieved through a comprehensive set of government policies and institutions that were being able to minimize the PPI risks to its lowest levels, and its effective allocation among the PPI partners. A further improvement in Korea's risk sharing approach through the introduction of the BTL scheme, have helped Korea to expand PPI scope to the social and Fnvironment Sectors. According to the PPI international experiences, the PPI have taken place mainly in economic infrastructure, such as telecommunication, power, and transportation. However, recently, attention has turned to expand its scope to reach social infrastructure, such as education, health, and housing, as well as environmental sector.

As Korea started to pay more attention to the social development as an important catalyst for achieving an economic development; the Korean Government started to increase its spending for the social welfare to reach the OFCD average. In order to support the government social development plan, the PPI scope was expanded 
from the economic to the social infrastructure sectors in 2005. The Korean experience provides evidences for the importance of the PPI in enhancing the performance of the Social and Environment Infrastructure Sectors. A similar program had been adopted in Fgypt since June, 2006, seeking to expand PPI scope to the social, and environment sectors such as; Education, Water and Sewage, and Health. Nevertheless, The Figyptian new PPI program is considered to be in its early stages of developments, where all PPI projects are still in the selection process. and the first Projects are set to start implementation through the period 2008 2012.

On Comparing the Egyptian PPI system to the Korean Model, it was found that the Egyptian PPI program complies greatly with the one implemented by South Korea and that in terms of the following:

- Similar PPI Structure and Procedures in both countries including: The responsikle bodies handling the system, the criteria at which the procurement process is based Value of money VFM, and the steps by which the PPI eligible facility types are chosen.

- In Both countries, within the PPT model, a sp ecific concern is provided to two specific sectors within the Social and Environment sector which are; Education, and Sewage system: The largest Portion of the PPI investment for the Social and Environment is allocated to those sectors.

Although the similar structure and procedures of the PPT system in the two countries, the Korean PPI system achieved tremendous advancement, however Egyptian PPI system is considered to be in its exrly stages of developments. On comparing the PPI system for the two countries it was noticed that the Egyptian PP system does not employ a PPI risk sharing approach. In Korea, a new risk sharing approach was achieved through a sucoessive government enabling role: policies and institutions that were being able to minimize the PPI risks to its lowest levels, and effectively allocate the risk among the PPI partners. The Egyptian PPI system lacks the necessary government policies, and effective institutions that decide on selecting, and allocating the risks among the PPI partners, thereby leading the Egyptian PPI system to be incapadule of employing a risk sharing approach and which is considered to be necessary for improving the PPI performance. Accordingly, as can be drawn from the Korean PPI model, it could be suggested that in order to enhance the efficiency of the Egyptian PPI system, the Egyptian PPI system has to enhance the efficiency of its regulatory and institutional framework by achieving a set of 
amendments, as could be extracted from the Korean model, including the following;

- A Specific law for PPI Projects (Act on Private Participation in Infrastructure PPI) and which offers thefollowing benefits:

(1) Within the framework of the PPI Act the PPI Projects are provided a set of incentives, and which could not be provided without a separate law for PPI projects.

(2) The Act issues Annual Plan that included the yearly planned PPI projects thereby avoiding the case that the parliament has to ratify the case by case PPI project

(3) The Korean PPI Act provides international fixed norms and standards for PPI projects instead of the appointment of a case by case inter national advisor for each project.

- The Korean Model employed an effective risk allocation and which was achieved through improving the evaluation techniques of the PPI selection process as follows:

(1) Establishment of PIMAC (Institutional Reform) as a separate institution that improved the evaluation of the PPI selecting process, and effectively allocates the risks between the PPI partners, in addition to its important role as a one-stop service for the PPI investors.
- Also as a part of the New Risk sharing approach employed by the Korean Model was the introduction of a new Risk Sharing Mechanisms, at which government Share portion of PPI risk with private sector, and that in away to minimize PPT Risks that mighth appen through PPI long life contracts 25-30. These Risks haring mechanism sin cluded the following: Minimum Revenue Guarantee MRG, Risk Mitigation for foreign Fxchange Risks, Buy out Rights \& Compensationon Termination Payments

- The Korean Model provided incentives to Private Sector to induce him to invest in PPI Projects including the following:

(1) Introduction of Unsolicited Projects.

(2) Providing the private sector a set of preferred tax treatments, and construction subsidies.

(3) The Establishment of Korea Credit Guarantee Fund as a separate organization that provides credit gua rantees for PPI projects.

- The Korean Model employed further developments for the Risk Sharing Approach to expand the PII scope from economic to the social infras tructure and which wasd one through the introduction of the BTL Scheme in 2005. 
The Korean experience provides evidences for the importance of the PPI in enhancing the performance of the Social and Environment Infrastructure Sector. Also, it provides evidences of the importance of the BTL scheme in promoting the PPI for those sectors. Where the benefits provided by a BTL Scheme for those Sectors could be as follows:

1-The BTL introduces an efficient risk sharing mechanisms by transferring the construction, and operational risks to more than one private party, thereby; the govemment would be acquiring services, rather than assets in Social infrastructure projects.

2-Improving the efficiency of the ser vice delivery through the Government supervisory Role. Within a BTL Scheme the govermment role is being away of the construction, and maintenance tasks, thereby enlancing the government role to be focused on the service supply and supervisory only, and which result in improving the efficiency of the infrastructureservices delivery.

3- Providing a room for the SMF to participate in PPI projects. In PPI projects, large construction companies have problems in preparing several projocts due to the lack of manpower, on the other hand SMEs are not qualified to take charge of projects due to lack of capital and technology. The BTL scheme has the advantage of the inclusion of many private parties in each PPI project providing by that a room for the SMFs to participate in the PPI projects. Promoting SMEs role in infrastructure projects is crucial due to their importance as an engine for economic growth.

4- The BTL is considered to be more suitable for the social infrastructure facilities, as theses sectors have the common characteristics of: low retum, and difficulty to obtain return in investment. And which is assured by a regular payment to the private sector, instead of colleting the users fees.

5- The Change in the Government regulations does not lead to project failure, as the private sector is paid regular installments. For instance, in the schools the government can easily change the regulations regarding the number of students in class, or education hours, or usage of building after school hours for other activity.

6- Effective Risk allocation of PPI tasks among the different parties according to the concept of the best to control and mange. Risk diversification leads each party to be specialized in his own task in PPI project. 
thereby enhancing the projec t efficienc $y$.

Finally, this paper clarifies that even though the efforts done by the Egyptian government in promoting the PPI in infrastructure, the infrastructure challenges in Egypt remains in a prominent position. The challenges facing the education and sewage sectors are considered to be severe, and the only remaining gateway for confronting the infrastructure challenges is promoting the PPI role, and which could not be achieved without a successful PPI system capable of inducing the private sector to invest in the PPI projects. Given that, the Fgyptian new PPI program for the social and environment sector is in its early stages of development, and since a similar program that had been employed by South Korea had achieved tremendous success. Accordingly, the Korean experience could draw important lessons to the government of Egypt on how to achieve PPI success for those sectors. As could be observed from the Korean PPI experience a successful PPI model entails the employment of a risk sharing approach capable to minimizing the PPI risks to its lowest levels through effectively allocating the risks among the PPI partners. The Korean Model provides lessons for the Arab Republic of Egypt about the importance of the government enabling role in employing a risk sharing approach through a set of institutional and regulatory reform amendments. 


\section{References}

Allard, Gayle, and Amanda Trabant. 2008. "Public-Private Partnerships in Spain: Lessons and Opportunities." International Business \& Economics Research Journal Volume 7 No.2

Asian Develooment Bank (ADB). 2008. "Public-Private Partnership Handbook. Manila, Philipp in es: ADB."

Eggers, William, and Tiffany Dovey. 2006. "Closing America's Infrast rudure Gap: The Role of Public-Private Partnerships." Deliotte Research Study.

Egypt. Ministry of Finance. Public Private Partnership Central Unit. 2008. "PPP Developments in Egypt." Presented at World Bank Egypt PPP Development conference in Egypt May 12th, 2008.

Egypt. Ministry of Finance. Public Private Partnership Central Unit. 2007. National Program for Public Privale Partnership (PPP). PPP Central Unit: Cairo, Egypt.

Egypt. Ministry of planning. Institute of National Planning. 2005. Egypt Human Development Report(HDR) Choosing our Future: Towards a New Social Contract Ministry of Planning, Cairo, Egypt.

Flannery, Angela, and Clive Craven. 2002 "PPP: Key Legal Issues." Presented at Asia Pacific Loan Market Association APLMA PPP Conference on May 2002 by Clayton UTZ Legal Advisory International Corporation.

Ho, S. Ping. 2007 Government Policy on PPP Financial Issues : Bid Compensation and Financial Renegotiation. Taiwan: National Taiwan University.

Jefferies, Marcus, Denny McGeorge, Katie Cadman, and Eng. 2007. "Public Private Partnership: The Provision of Social Infrastructure in Australia." Presented at ClB World Building Congress: 1782-1792.

Korea Ministry of Planning and Budget. 2007. Annual infrastructure Report: Country Infrastructure Report lor the High-level Expert Group Meetingon Public-Private Partnerships for Infrastructure Development. MPB

Korea Ministry of Strategy and Finance (MOSF). 2008a.

"Korean PPI System: Introduction in PPI System."

(http://o pi.mpb.go.kr/pp iSystem_introdudion. jsp?conn_jspnm=ppiSystem_introductio n.jsp) (December 21, 2008). 
$\mid$

Korea Minislry d Strategy and Finance (MOSF). 2008a.

"Korean PPI System: BTL Scheme"

(http://poi.mpb.go.kr/im plementationSchem es_BTL.jsp?con n_jspnm=im plementation Schemes_BTL.jsp) (December 21, 2008).

Korea. Ministry of Strategy and Finance (MOSF). 2008c.

"Korean PPI System: Introduction in Implementation Schemes."

(hltp://ppi.mpb.go.kr/implementationSchem es_schemes.jsp ?conn_jspn m-implement ationSchemes_schemes.jsp) (December 21, 2008).

Korea Ministry of Strategy and Finance (MOSF). 2008d. "Private Participation in Infrastruclure in Korea" presented at the Asia Pacific Economic Cooperation Conference in Lima, Peru 1314 August 2008.

Korea Research Institute for Human Settlements (KRIHS). 2005. Infrastructure \& Construction Economics Research Division. Inf rastructure Facility Development and Financing Policie sin Korea Gyeongg i-do, South Korea.

lossa Elisabetta, and David Martimort. 2008. The Simple Micro-Economics of PublicPrivate Partnerships. Brunel University, UK.

Organization for Economic Co-Operation and Development (OECD). 2007. Principles for Private Sector Participation in Infrastructure. France: OECD.

Parker, David. 2007. Intrast rudure Developm ent and Privatizalion

: Limitations of the New Economic Paradigm. Cranfield, UK: Cranfield University.

Quiggin, John. 2006. "Public Private Partnership: Options for Improved Pisk Allocation." The University of New South Wales Law Journal Volume 29(3): 2893-293

Rawlings, Lisa.2002 "Innovative Methods to Fund Public Schools Construdion." University of Maryland School of Public Affairs.

Spellman, David, and Walker. 2006. Public Private Partnership: Practice and Regulatory Policy inKenya. Kenya: The Institute of Economic Affairs.

United Nation Economic and Social Commission for Asia and the Pacific (UNESCAP). 2007a Rep ort of High-Level Export Group Meeting for Asia and Pacific, Seoul 2- 4 October 2007. Bangkok, Thailand: UNESC AP.

World Bank (WB). 2007a. Public-Private Partnership Units : Lessons for their Design and Usein Infrastructure. Washington DC:World Bank.

Weatherall, Michael. 2004. "Public Private Partnerships: A New Zealand Overview." Presented at the Pacific Economic Cooperation Council PECC in New Zealand. 